\title{
(8)
}

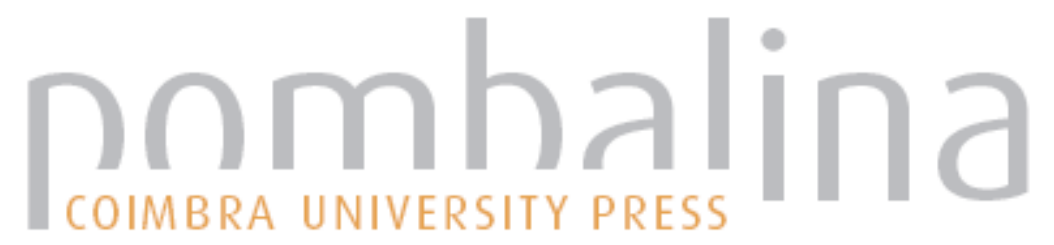

\section{High resolution weather forecasting applied to forest fire behaviour simulation}

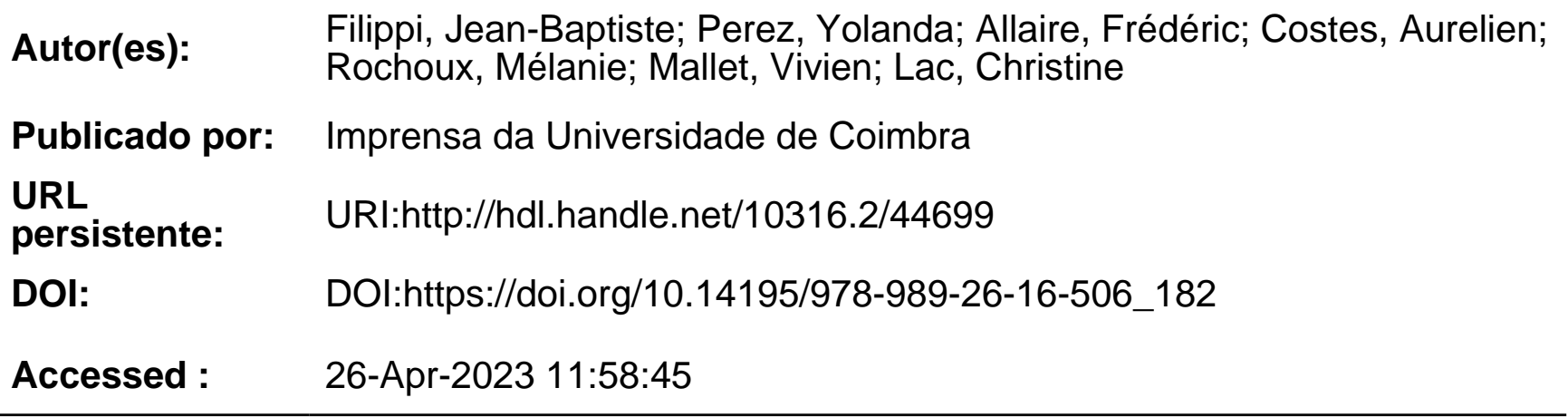

A navegação consulta e descarregamento dos títulos inseridos nas Bibliotecas Digitais UC Digitalis, UC Pombalina e UC Impactum, pressupõem a aceitação plena e sem reservas dos Termos e Condições de Uso destas Bibliotecas Digitais, disponíveis em https://digitalis.uc.pt/pt-pt/termos.

Conforme exposto nos referidos Termos e Condições de Uso, o descarregamento de títulos de acesso restrito requer uma licença válida de autorização devendo o utilizador aceder ao(s) documento(s) a partir de um endereço de IP da instituição detentora da supramencionada licença.

Ao utilizador é apenas permitido o descarregamento para uso pessoal, pelo que o emprego do(s) título(s) descarregado(s) para outro fim, designadamente comercial, carece de autorização do respetivo autor ou editor da obra.

Na medida em que todas as obras da UC Digitalis se encontram protegidas pelo Código do Direito de Autor e Direitos Conexos e demais legislação aplicável, toda a cópia, parcial ou total, deste documento, nos casos em que é legalmente admitida, deverá conter ou fazer-se acompanhar por este aviso.

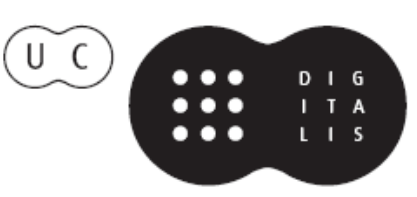




\section{ADVANCES IN}

\section{FOREST FIRE RESEARCH}

\section{8}

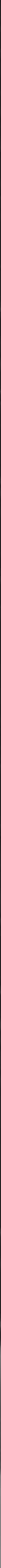


Short contribution - Decision Support Systems and Tools

High resolution weather forecasting applied to forest fire behaviour simulation

\author{
Jean-Baptiste Filippi ${ }^{1 *}$; Yolanda Perez ${ }^{1}$; Frédéric Allaire ${ }^{2}$; Aurelien Costes $^{3}$; Mélanie Rochoux ${ }^{4}$; Vivien \\ Mallet $^{2}$; Christine Lac ${ }^{3}$. \\ ${ }^{1}$ SPE - UMR 6134 CNRS. Université de Corse, France. \{filippi@univ-corse.fr*, perez-ramirez@univ- \\ corse.fr \} \\ ${ }^{2}$ Team ANGE (Inria, CEREMA, UPMC, CNRS). 2 rue Simone Iff, CS 42112, 75589 Paris Cedex 12, France \\ and Sorbonne Universités, UPMC Univ. Paris 06, \\ Lab. Jacques-Louis Lions UMR CNRS 7598, 75005 Paris, France \\ \{frederic.allaire@inria.fr,vivien.Mallet@inria.fr\} \\ ${ }^{3}$ CNRM, Météo-France-CNRS,Toulouse,France. \{aurelien.costes@meteo.fr, christine.lac@meteo.fr\} \\ ${ }^{4}$ CECI, Université de Toulouse, CNRS, CERFACS, 42 Avenue Gaspard Coriolis, 31057 Toulouse cedex 01, \\ France.\{melanie.rochoux@cerfacs.fr\}
}

Keywords: simulation ; wildfire ; high performance computing ; fire meteorology

Availability of supercomputers and new high-resolution data sources (such as Sentinel satellites or airborne LIDAR) are providing new ways of forecasting fire behaviour, opening the opportunity to have better fuel description, perform large probabilistic forecasts and data assimilation of fire/weather coupled models. Several codes using high performance computing already exist, with methods and services for forest fire forecasting developed through major innovations such as a coupled highresolution fire/atmosphere model (Coehn et al, 2013; Mandel et al, 2011; Filippi et al, 2013) data assimilation (Zhang et al 2017) of fire front positions, and ensemble simulations for uncertainty evaluation (Finney et al 2011).

High-resolution (sub km)/high-frequency ( $<10$ minutes) weather forecasting is in particular among the major enhancements allowed by the availability of such tools because it does reach relevant scales for day-to -day forest fire behavior wind forcing, but also fuel moisture and data assimilation.

FireCaster simulation chain is an experiment to develop integrated tools, methods, datasets and uses of such tools in an operational context. Its core is a daily computer intensive batch run of the mesoscale weather forecasting model Meso-NH (Lac et al 2017) initialized with the French national service Arome model, parameterized with a $600 \mathrm{~m}$ horizontal resolution, with outputs every 2 minutes for a $42 \mathrm{~h}$ forecasting duration.

One of the major use of such kind of run providing fire-specific zoomed view of a high risk area, then, in case of fire, specific input parameters for different kinds of interactive (controlled by an operator) fire behavior simulations (fire propagation, ensemble-based fire probability), taking into account fuel moisture and specific high resolution land use of the fire area (fig. 1) to test fighting scenarios with sub minute simulation time.

The other decision support tool for on-demand simulation is the fire weather forecast, deterministic $\mathrm{H}+6$ to $\mathrm{H}+12$ front positions, smoke and micro-meteorology forecasts every hour to be able to alert population and derive precise estimate of the front advance. Fire/weather simulation is using here Meso-NH code coupled with ForeFire (Filippi et al, 2013). This coupled code is run on-demand, in case of an effective fire ignition to estimate specific fire weather event (fire effect on local winds, coupled effect on fire), very local pollution and smoke dispersion. 


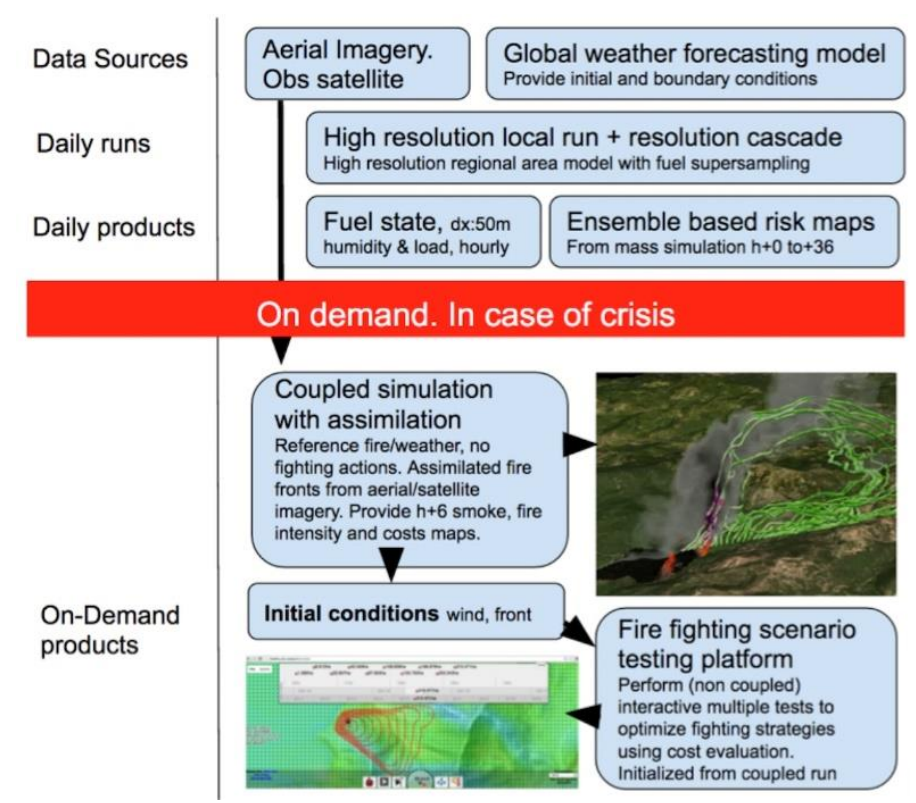

Figure 1 - Overall view of the components in the tool-chain

The main challenge is that both day-to-day and crisis, on-demand models share the same components (fuel model, ensembles) that have been developed to be interoperable, implying that not only the data format but also the physical fields (resolutions, definitions) were coherently designed.

The tool-chain aims to reach a national scale and has been running experimentally since May 2017 over the island of Corsica. Several large fires occurred in this fire season giving the opportunity to tests the tool-chain by operational services, requiring to develop specific new ways of delivering the information of the high-resolution weather forecasting model (online video with focus on specific areas) and a rapid response web-based fire propagation tool. While the user interface and information delivery are still requiring enhancement, it appeared to be a relevant decision support system in specific complex terrain or meteorological situations where quick local effects are of major importance.

An example is the Calenzana Fire where a sudden wind shift allowed a strong foehn wind and quick rise in temperature, well captured by the model (Figure 2), with the animation and high resolution of the meteorological fields providing a different understanding of the situation.
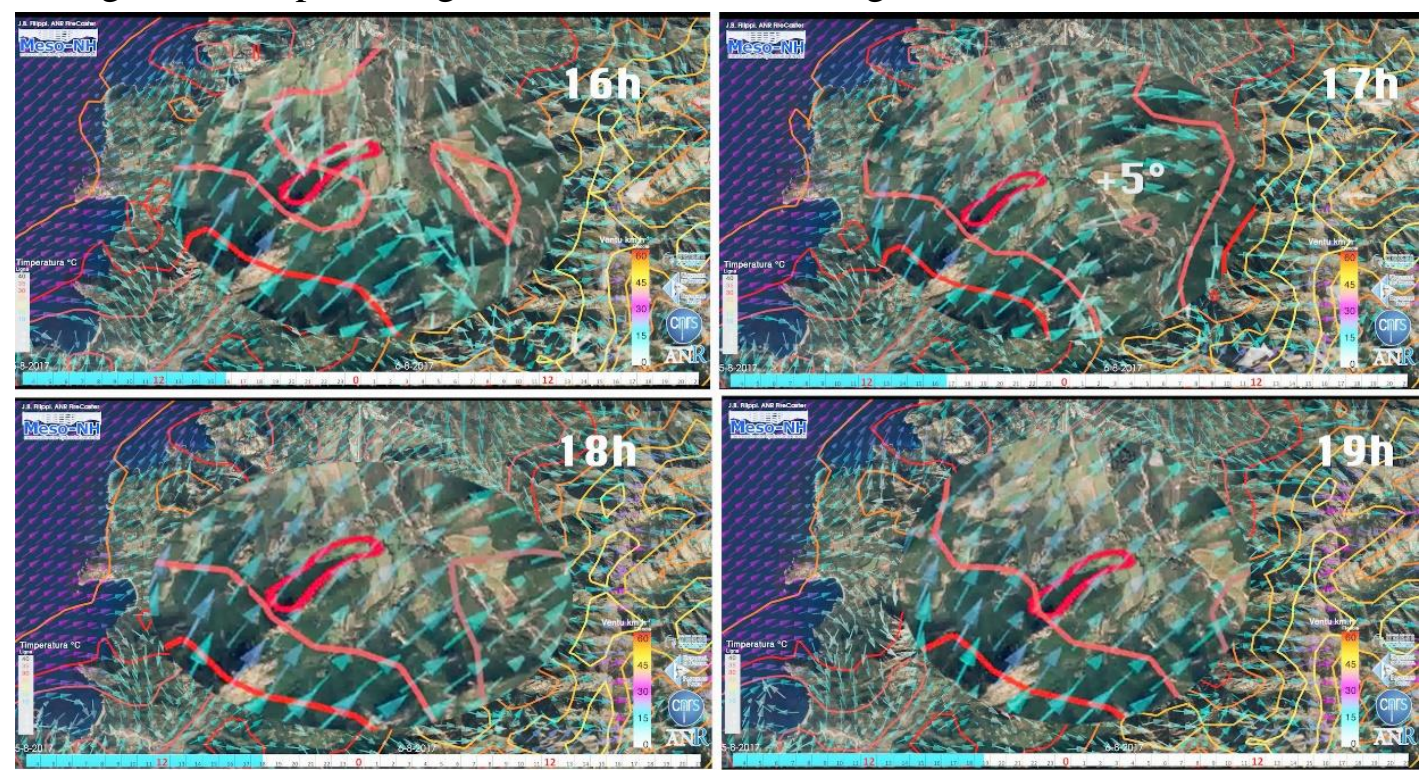

Figure 2 - Calenzana Fire, Aug. 6. 2017. Fire Area in Red. Temperatures as isolines, wind as vectors. FireCaster forecast view at 16:00 (top left), 16:00 (top right), 18:00 (bottom left), 19:00 (bottom right). 
Rapid response web simulation of the fire (available in less than 2 minutes) also allowed to guess the possible extent of the fire (figure 3), and evolution. Fortunately this fire was very quickly handled by firefighters and almost stopped in less than 2 hours.

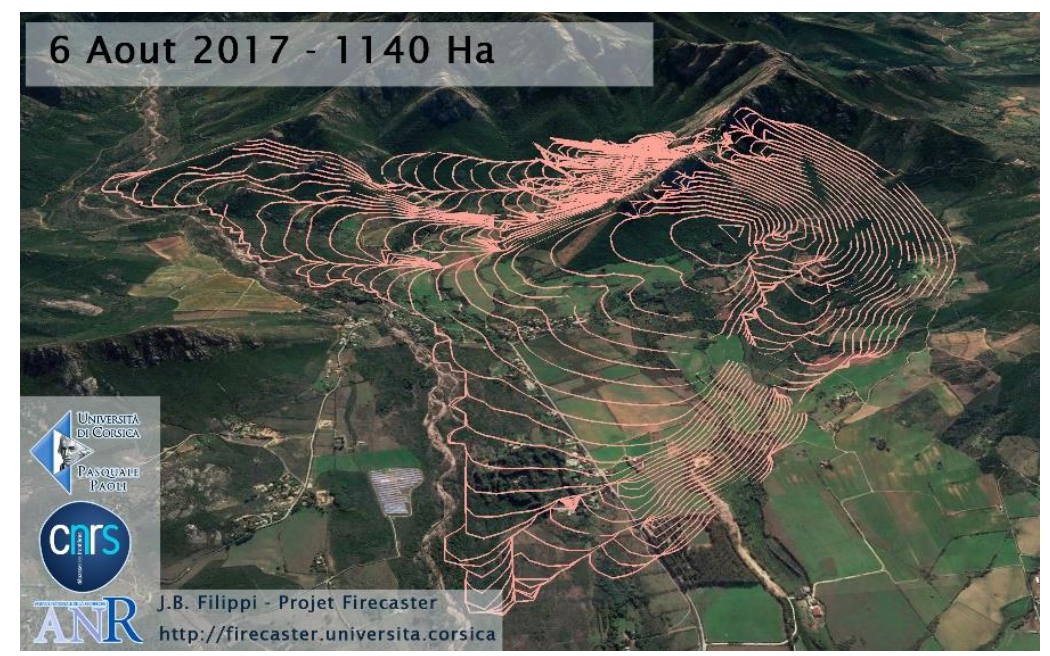

Figure 3 - Rapid-Response simulation, without firefighting actions. Fire as pink 20 minutes isolines, 7 hours total duration.

Rapid response smoke dispersion model is still only experimental and will be tested in the summer 2018 in case of fire. Overall, FireCaster tool-chain requires 240 processors 8 hours and 120 Go of data archiving per day. In 2017, six 2 minutes online videos were produced daily and more than 800 simulation performed, with all simulation tools and results available on the program website.

\section{References}

Coen, J. L., Cameron, M., Michalakes, J., Patton, E. G., Riggan, P. J., \& Yedinak, K. M. (2013). WRFFire: Coupled Weather-Wildland Fire Modeling with the Weather Research and Forecasting Model. Journal of Applied Meteorology and Climatology, 52(1), 16-38. https://doi.org/10.1175/jamc-d-12-023.1

Mandel, J., Beezley, J. D., \& Kochanski, A. K. (2011). Coupled atmosphere-wildland fire modeling with WRF 3.3 and SFIRE 2011. Geoscientific Model Development, 4(3), 591-610. https://doi.org/10.5194/gmd-4-591-2011

Assessment of ForeFire/Meso-NH for wildland fire/atmosphere coupled simulation of the FireFlux experiment, J.-B. Filippi, X. Pialat, C.-B. Clements, Proceedings of the Combustion Institute, Volume 34, Issue 2, Pages 2633-2640, 2013.

C. Zhang, M.C. Rochoux, W. Tang, M.J. Gollner, J.-.B. Filippi \& A. Trouvé: Evaluation of a datadriven wildland fire spread forecast model with spatially-distributed parameter estimation in simulations of the FireFlux I field-scale experiment, Fire Safety Journal, vol. 91, pp. 758767, doi: 10.1016/j.firesaf.2017.03.057

Finney, Mark A., McHugh, Charles W., Grenfell, Isaac C., Riley, Karin L., Short, Karen C., 2011. A simulation of probabilistic wildfire risk components for the continental United States. Stochastic Environmental Research and Risk Assessment. 25, 973-1000.

Lac, C., Chaboureau, J.-P., Masson, V., Pinty, J.-P., Tulet, P., Escobar, J., ... Wautelet, P. (2018). Overview of the Meso-NH model version 5.4 and its applications. Geoscientific Model Development Discussions, 1-66. https://doi.org/10.5194/gmd-2017-297 